\title{
Impact of drying and cooling rate on the survival of the desiccation-sensitive wheat pollen
}

\author{
Daniela Impe $^{1,2}$ D $\cdot$ Daniel Ballesteros ${ }^{3,4}$ (D) Manuela Nagel ${ }^{1}$ (D)
}

Received: 12 August 2021 / Accepted: 22 November 2021 / Published online: 31 January 2022

(c) The Author(s) 2022

\begin{abstract}
Key message Fast-drying and cooling induce fast intracellular water loss and reduced ice-crystal formation, which may promote the formation of intracellular glasses that might improve the likelihood of wheat pollen survival.

Abstract Long-term storage of pollen is important for the fertilization of spatially or temporally isolated female parents, especially in hybrid breeding. Wheat pollen is dehydration-sensitive and rapidly loses viability after shedding. To preserve wheat pollen, we hypothesized that fast-drying and cooling rates would increase the rate of intracellular water content (WC) removal, decrease intracellular ice-crystal formation, and increase viability after exposure to ultra-low temperatures. Therefore, we compared slow air-drying with fast-drying (dry air flow) and found significant correlations between pollen WC and viability $(\mathrm{r}=0.92, P<0.001)$; significant differences in WCs after specific drying times; and comparable viabilities after drying to specific WCs. Fast-drying to WCs at which ice melting events were not detected $\left(\Delta \mathrm{H}=0 \mathrm{~J} \mathrm{mg}^{-1} \mathrm{DW},<0.28 \mathrm{mg}\right.$ $\mathrm{H}_{2} \mathrm{O} \mathrm{mg}^{-1} \mathrm{DW}$ ) reduced pollen viability to $1.2 \pm 1.0 \%$, but when drying to $0.39 \mathrm{mg} \mathrm{H}_{2} \mathrm{O} \mathrm{mg}^{-1} \mathrm{DW}$, some viable pollen was detected $(39.4 \pm 17.9 \%)$. Fast cooling $\left(150{ }^{\circ} \mathrm{C} \mathrm{min}^{-1}\right)$ of fast-dried pollen to $0.91 \pm 0.11 \mathrm{mg} \mathrm{H}_{2} \mathrm{O} \mathrm{mg}^{-1} \mathrm{DW}$ induced less and a delay of ice-crystal formation during cryomicroscopic-video-recordings compared to slow cooling $\left(1{ }^{\circ} \mathrm{C} \min ^{-1}\right)$, but viability was low (4.5-6.1\%) and comparable between cooling rates. Our data support that the combination of fast-drying and cooling rates may enable the survival of wheat pollen likely due to (1) a reduction of the time pollen would be exposed to drying-related deleterious biochemical changes and (2) an inhibition of intracellular ice-crystal formation, but additional research is needed to obtain higher pollen survival after cooling.
\end{abstract}

Keywords Cryomicroscopy $\cdot$ Differential scanning calorimetry $\cdot$ Hybrid breeding $\cdot$ Impedance flow cytometry $\cdot$ Pollen viability

Communicated by Emmanuel Guiderdoni.

Manuela Nagel

Nagel@ipk-gatersleben.de

1 Leibniz Institute of Plant Genetics and Crop Plant Research (Leibniz-IPK), Corrensstraße 3, 06466 Seeland OT Gatersleben, Germany

2 Present Address: Institute of Experimental Botany of the Czech Academy of Science, Rozvojová 263, 16502 Prague 6, Czech Republic

3 Royal Botanic Gardens Kew, Wakehurst Place, Ardingly RH17 6TN, UK

4 Present Address: Universitat de Valencia, Facultad de Farmacia, Av. Vicent Andres Estelles s/n, 46100 Burjassot, Spain

\section{Introduction}

Preservation of pollen from flowering plants is an important way to complement plant biodiversity conservation efforts and to widen genetic diversity in breeding programs. The storage of haploid male gametophytes allows fertilization of spatially or temporally isolated parents and supports reproduction in the absence of efficient and effective pollinators (Dinato et al. 2020). Wheat (Triticum aestivum), the second most produced crop (http://www.fao.org/faostat/), develops desiccation-sensitive pollen which has completed second pollen mitosis and is tricellular before shedding. This pollen type is ready to germinate upon landing on the stigma (Brewbaker 1967; Franchi et al. 2002) and loses its viability when exposed to ambient laboratory conditions for $60 \mathrm{~min}$ or to field conditions for $30 \mathrm{~min}$ (D'Souza 1970). So far, the time to pollinate the female parents during crossing and 
hybrid breeding trials is limited to a short time window and only little information has been reported on its desiccation and low-temperature stress tolerance. Therefore, studies on long-term storage of viable wheat pollen would be of high interest to support preservation, accelerate breeding programs, and to promote new breeding options.

Most pollen grains have water contents (WCs) below 30\% (fresh weight (FW) basis) at dispersal and are termed desiccation-tolerant, partially dehydrated or orthodox. This pollen type is often small, between $30 \mu \mathrm{m}$ and $100 \mu \mathrm{m}$ (Pacini and Franchi 2020), and is able to be stored at low WCs $(<15 \% \mathrm{FW}$ basis) and low temperatures for longer periods (Dinato et al. 2020). The low WCs do not favour ice-crystal formation and, thus, freeze-injuries during storage at sub-zero temperatures or ultra-low temperatures $\left(<-150^{\circ} \mathrm{C}\right)$ (Dinato et al. 2020). To achieve low WCs, pollen is often dried until the cytoplasm enters to a metastable solid state known as the glass (Buitink et al. 1996). Drying may be performed naturally at anthesis, or forced at ambient conditions (if relative humidity $(\mathrm{RH})<75 \%$ ), above salt solutions (Connor and Towill 1993) or silica gel (Walt and Littlejohn 1996). Protocols for dry storage at low or ultra-low temperatures have been employed for pollen of various crops (Hecker et al. 1986; Sacks and Clair 1996; Souza et al. 2018), medicinal plants (Gaudet et al. 2020), woody trees (Alba et al. 2011; Maryam et al. 2017; Zhang et al. 2017), ornamental plants (Geng et al. 2013; Xu et al. 2014), and endangered species (Rajasekharan et al. 2013).

Pollen grains that have WCs above 30\% (FW basis) at dispersal, termed desiccation-sensitive, partially hydrated or recalcitrant, are often bigger (15 to $150 \mu \mathrm{m})$ (Pacini and Franchi 2020) and hardly tolerate water loss below 30\% (FW basis). To store dehydration-sensitive pollen, the levels of WC reached must be carefully balanced, and stay higher to those that generate desiccation damage and lower or close to the limit to those in which water can freeze (Nebot et al. 2021). For desiccation-sensitive pollen of some members of the Poaceae family, e.g. maize (Zea mays) (Barnabás and Rajki 1976; Nath and Anderson 1975), pearl millet (Pennisetum glaucum) (Hanna 1990), protocols for cryogenic storage were successfully developed. The additional application of rapid dehydration by a stream of dry air showed to increase the survival to low WCs and to improve the cryostorage success of embryonic axes of various desiccation-sensitive seeds (Berjak et al. 1993; Pammenter et al. 1991, 1998; Wesley-Smith et al. 2001a, b) and has been applied to pollen of maize (Buitink et al. 1996; Nebot et al. 2021).

Besides drying, pollen viability can be affected by cooling speed, i.e., slow vs. fast cooling, during the cryogenic procedure (Dinato et al. 2020). In general, for cells, tissues, or small organs, slow cooling is often conducted in two steps. After samples are cooled at 0.1 to $5{ }^{\circ} \mathrm{C} \mathrm{min}^{-1}$ down to -35 to $-40{ }^{\circ} \mathrm{C}$ which is above the ice nucleation temperature, samples are exposed to liquid nitrogen (LN) for long-term storage. Most intracellular water is removed by freeze dehydration. If applied, cryoprotective substances such as dimethyl sulfoxide (DMSO) interact and modulate the distribution of water in- and outside the cell. Fast cooling applies cooling rates of $>100{ }^{\circ} \mathrm{C} \mathrm{min}^{-1}$ to enable vitrification processes (Wolkers and Oldenhof 2021). Biological systems vitrify when cell viscosity increases, glassy structures are formed, and water molecules are prevented from aggregating into larger ice crystals (Ganeshan et al. 2008). To increase intracellular viscosity, often cells or small organs are exposed to dehydrating agents such as Plant Vitrification Solutions (PVS) which consist of sucrose, glycerol, and DMSO (Fahy and Wowk 2015). Nevertheless, re-crystallization events can occur during warming and affect the viability (Bajaj 1985; Mazur 1984; Meryman and Williams 1985). Therefore, rapid warming by immersing the samples in a warm water bath at 37 to $40^{\circ} \mathrm{C}$ for 1 to $5 \mathrm{~min}$ is often applied (Ganeshan et al. 2008). The kinetics of intracellular ice formation accompanying cooling and warming can be recorded by advanced video-cryomicroscopy (Karlsson 2015) introduced in 1971 (Diller and Cravalho 1971). This technology has been frequently used in cryopreservation studies of mammalian cells (Scheiwe and Korber 1984; Stott and Karlsson 2009), but its application in plant cryopreservation is still novel. As it provides additional data to assess the risk of cryoinjury (Karlsson 2015), it may guide further advancements in the cryopreservation procedure of, i.e., dehydration-sensitive pollen.

The aim of our study is to investigate systematically the relationship between drying rate, pollen $\mathrm{WC}$, and cooling rates on wheat pollen viability before and after exposure to ultra-low temperatures. Video-cryomicroscopy and differential scanning calorimetry (DSC) were employed to monitor events of ice crystallization in wheat pollen dried at two drying rates, to test the hypotheses that (1) pollen desiccation tolerance increases in fast-dried compared to slow air-dried pollen, (2) ice crystallization can be reduced in fast-dried and fast-cooled desiccation-sensitive pollen, and (3) the higher desiccation tolerance of fast-dried pollen allows a higher survival after rapid cooling. Results obtained are discussed in relation to main reasons for wheat pollen damage during dehydration and cooling, and are used to recommend further protocol improvements for the cryopreservation of wheat pollen.

\section{Materials and methods}

\section{Plant material and pollen sampling}

Seeds of the spring wheat lines TRI 9102 (https://doi.org/ 10.25642/IPK/GBIS/9074) and TRI 3633 (https://doi.org/ 10.25642/IPK/GBIS/3633) were provided by the Federal Ex situ Gene Bank of agricultural and horticultural plants at IPK Gatersleben. Seeds of the winter wheat line 'Ferrum' (KWS, licensed since 2012) were commercially available. Seeds were germinated in a standard culture medium 
(Substrate1, Klasmann-Deilmann GmbH, Geeste, Germany) at $20 \pm 2{ }^{\circ} \mathrm{C}$. One-week old seedlings were subjected to $4 \pm 1^{\circ} \mathrm{C}$ for 4 weeks. Vernalized plants were transferred into pots containing a sand/soil mixture (70\% compost soil, $20 \%$ white peat, $10 \%$ sand) and grown under optimum conditions (regular watering and fertilization, $16 \mathrm{~h}$ light) at $20 \pm 2{ }^{\circ} \mathrm{C}$ in the greenhouse.

At the beginning of anthesis, spikes were cut between 8:00 and 10:00 a.m., kept in water and used within 6 h. Only mature pollen was used for all experiments. To stimulate pollen maturation, awns, glumes, and lemmas were carefully removed and pollen was sampled when lodicules swelled, the stigma fanned out, filaments elongated, and anthers enlarged and turned greenish to bright yellow (Impe et al. 2020). Before the tip of the anther opened, at minimum three anthers were taken and pollen shedding was supported by opening gently with a needle. Mature pollen was used immediately after anthesis as a control and termed 'fresh'. Due to different flowering times, pollen of different wheat lines had to be used for different experiments.

\section{Pollen treatment and water content}

Fresh mature pollen was collected from 5 to 8 anthers of one spike, transferred to a mesh of pore size $30 \mu \mathrm{m}$, and fixed with a second layer of mesh in a so-called flash-dryer according to Buitink et al. (1996) and Nebot et al. (2021). The pollen was exposed to a stream of dry air $(10.7 \pm 0.1 \%$ $\mathrm{RH})$ equilibrated above $250 \mathrm{~g}$ silica gel at room temperature which reached equilibrated RH 4 min after opening. By this method, pollen was fast-dried for 1, 2, 3, 5, 7, 10, 12, 15, 20, and $60 \mathrm{~min}$ and corresponding RHs are given in Figure S1. Pollen air-dried at $60.0 \pm 0.1 \% \mathrm{RH}$ and room temperature $\left(23.0 \pm 0.4{ }^{\circ} \mathrm{C}\right)$ for $10,20,30,40$, and 60 min was used as a reference of slow-dried pollen, and fresh pollen served as a reference of non-dried pollen.

Pollen WC was measured on a set of fresh, fast-dried, and air-dried pollen. Pollen was transferred in an aluminium pan, hermetically sealed, and weighted. To determine pollen WC, pans were perforated and exposed to $100{ }^{\circ} \mathrm{C}$ for $24 \mathrm{~h}$. Afterwards, pans were re-weighted and the difference between FW and dry weight (DW) was calculated and expressed as $\mathrm{mg} \mathrm{H}_{2} \mathrm{O} \mathrm{mg}{ }^{-1} \mathrm{DW}$ (1) or percentage of FW (2)
Then WC values were plotted against drying time and drying curves were built for each wheat line and drying method. Drying rates were calculated for the first part of the drying curve ( 0 to $10 \mathrm{~min}$ ) in terms of $\mathrm{mg} \mathrm{H}_{2} \mathrm{O} \mathrm{mg}^{-1} \mathrm{DW}$ lost per minute (Ballesteros et al. 2014).

\section{Pollen viability}

Pollen viability was assessed by pollen germination and impedance flow cytometry (termed IFC viability) using at minimum four biological replicates each if not otherwise stated. Pollen was germinated on a solid medium containing $594 \mathrm{mM}$ raffinose, $0.81 \mathrm{mM} \mathrm{H}_{3} \mathrm{BO}_{3}, 2.04 \mathrm{mM} \mathrm{CaCl}_{2}$ at $\mathrm{pH}$ 5.8. Pollen tubes exceeding the lengths of the pollen radius were counted manually and expressed as percentage of germination. To determine IFC viability, pollen was transferred into $1 \mathrm{~mL}$ IFC buffer (AF6, Amphasys, Lucerne, Switzerland), filtered using $100 \mu \mathrm{m}$ pore size, and loaded onto a chip of $120 \mu \mathrm{m}$ channel size. The chip was inserted in the IFC (Ampha Z32, Amphasys, Lucerne, Switzerland) and measurements were carried out at $1 \mathrm{MHz}$ at the default settings for wheat pollen. IFC viability of at minimum 1000 pollen was analysed using AmphaSoft 2.0 version (Amphasys, Lucerne, Switzerland) and given as a percentage.

\section{Differential scanning calorimetry}

Fresh, air-dried and fast-dried pollen of TRI 9102 and 'Ferrum' were hermetically sealed in aluminium pans, weighted, and scanned using a DSC-Q2000 (Thermal Analysis Instruments, New Castle, USA) equipped with an LN cooling device. Measurements were carried out between $23{ }^{\circ} \mathrm{C}$ and $-150{ }^{\circ} \mathrm{C}$ using cooling/warming rates of $10^{\circ} \mathrm{C} \mathrm{min}^{-1}$. The onset of crystallization and melting events were determined from the intersection between the baseline and a line drawn from the steepest segment of the transition peak using the software Thermal Analysis v. 4.4. (Thermal Analysis Instruments, New Castle, USA). Baselines were determined using an empty aluminium pan as a reference. The enthalpy $(\Delta H)$ of the transition was determined from the area encompassed by the peak and the baseline (Ballesteros and Walters 2007). Exothermic and endothermic changes are expressed on a DW basis and were plotted against the pollen WC. Results

WC $\left[\mathrm{mg} \mathrm{H}_{2} \mathrm{O} \mathrm{mg}^{-1} \mathrm{DW}^{-1}\right]=\frac{\text { (Weight of fresh pollen }[\mathrm{mg}]-\text { weight of dry pollen }[\mathrm{mg}] \text { ) }}{\text { weight of dry pollen }[\mathrm{mg}]}$

$\mathrm{WC}[\%]=\frac{(\text { Weight of fresh pollen }[\mathrm{mg}]-\text { weight of dry pollen }[\mathrm{mg}])}{\text { weight of fresh pollen }[\mathrm{mg}]} \times 100$. 
were obtained from at least four replicates each for each drying treatment.

\section{Cryomicroscopy-video-recordings}

Fresh, air- and partially fast-dried pollen were used. Partially fast-dried pollen was dried for $5 \mathrm{~min}$ and kept still a high IFC viability $(\sim 80 \%)$ after drying, while the WC decreased to $0.91 \pm 0.11 \mathrm{mg} \mathrm{H}_{2} \mathrm{O} \mathrm{mg}{ }^{-1} \mathrm{DW}$. Although WC was likely above the levels of unfrozen WC (measured at about $0.20-0.40 \mathrm{mg} \mathrm{H}_{2} \mathrm{O} \mathrm{mg}^{-1}$ DW for seeds, fern spores, Typha latifolia or maize pollen (Ballesteros and Walters 2007; Buitink et al. 1996)), we presumed that this would reduce the risk of over-drying of pollen ( $<40 \%$ IFC viability) which may occur when pollen is dried for $10 \mathrm{~min}$, down to the unfrozen WC. For comparison, we also used fresh pollen and pollen dried for $60 \mathrm{~min}$ (WC $<0.06 \mathrm{mg} \mathrm{H}_{2} \mathrm{O} \mathrm{mg}^{-1} \mathrm{DW}$ ), which was at WC below the unfrozen WC $\left(<0.26 \mathrm{mg} \mathrm{H}_{2} \mathrm{O} \mathrm{mg}^{-1} \mathrm{DW}\right)$, but was completely dead. Pollen from different treatments were dusted onto glass plates and placed in the cryomicroscopic stage system (BCS196, Linkam Scientific Instruments, Tadworth, United Kingdom) which was mounted on a light microscope (Eclipse LV100, Nikon, Tokyo, Japan). The stage was connected to a T95-PE temperature control unit (Linkam Scientific Instruments, Tadworth, UK) and a Dewar vessel containing $\mathrm{LN}$. The temperature program and flow rates were controlled using LinkSys32 software (Linkam Scientific Instruments, Tadworth, UK). Pollen were exposed to slow $\left(1{ }^{\circ} \mathrm{C} \mathrm{min}{ }^{-1}\right)$ and fast cooling/warming $\left(150{ }^{\circ} \mathrm{C} \mathrm{min}^{-1}\right)$ in a range between 0 to $-40{ }^{\circ} \mathrm{C}$. Details are provided in Table 1 . Due to the high rates during fast cooling/warming, the means and standard deviations of temperatures for structural changes of pollen (i.e., darkening, pollen turn black and thawing) were interpolated based on temperature at the start, within the holding phase and at the end of the cooling program and a few temperature points in between taken at the time points when structural changes were visible.

Time-lapse and real-time videos recorded with a camera attached to the optical output of the microscope were used to monitor structural changes during cooling/warming. To evaluate significant events, NIS software (v. 4.11, Nikon Metrology, Brighton, USA) allowed the extraction of specific images for an exact time point. Three-to-six replicates for each of the six treatments including two cooling/warming programs and three drying treatments were prepared.

\section{Statistical analysis}

Means and standard deviations (SD) were calculated in Excel 365 (Microsoft, Richmond, CA, USA) and data are shown as mean \pm SD. Statistical analyses were performed based on unpaired Student's $t$ test. $P$ values $<0.05$ were considered significant; in the figures, *,**, and *** indicate significant differences at the $0.05,0.01$, and 0.001 levels of confidence, respectively, while no label indicates no significance. Using GenStat 19.1 (VSN International Ltd., 2016), Pearson correlation analysis was performed to find significant relationships at $P<0.05$ between drying method, WC and viability. To compare the drying rates, slopes of WCs were estimated by linear regression within the first $10 \mathrm{~min}$ and 20 min of drying. WC limits for pollen viability and germination were calculated using the effective dose function (probit analysis) in Genstat 19.1 (VSN International Ltd., 2016). Effective dose of WC was estimated at 60\% IFC viability and $20 \%$ pollen germination.

\section{Results}

\section{The viability of wheat pollen is affected by the drying rate and water content}

Immediately after shedding, pollen of the wheat lines 'Ferrum' and TRI 9102 had a steady high WC of $1.72 \pm 0.01 \mathrm{mg}$ $\mathrm{H}_{2} \mathrm{O} \mathrm{mg}{ }^{-1}$ DW $\left(63.3 \%\right.$ of FW) and $1.57 \pm 0.10 \mathrm{mg} \mathrm{H}_{2} \mathrm{O}$ $\mathrm{mg}^{-1} \mathrm{DW}(61.1 \%$ of $\mathrm{FW})$, respectively. After $10 \mathrm{~min}$ of drying, air-dried pollen of 'Ferrum' and TRI 9102 lost on average $62.9 \%\left(0.64 \pm 0.72 \mathrm{mg} \mathrm{H}_{2} \mathrm{O} \mathrm{mg}{ }^{-1} \mathrm{DW}\right)$ and $54.2 \%$ $\left(0.72 \pm 0.20 \mathrm{mg} \mathrm{H}_{2} \mathrm{O} \mathrm{mg}{ }^{-1} \mathrm{DW}\right)$ of the $\mathrm{FW}$, respectively.

Table 1 Cooling/warming programs used to monitor wheat pollen during cryogenic treatments

\begin{tabular}{|c|c|c|c|c|c|}
\hline Temperature program & Setting for video recording & Ramp & Temperature $\left[{ }^{\circ} \mathrm{C}\right]$ & $\begin{array}{l}\text { Flow rate }\left[{ }^{\circ} \mathrm{C}\right. \\
\left.\min ^{-1}\right]\end{array}$ & $\begin{array}{l}\text { Hold- } \\
\text { ing time } \\
{[\mathrm{min}]}\end{array}$ \\
\hline Slow cooling & Time-lapse video 1 frame per $5 \mathrm{~s}$ & $\begin{array}{l}1 \\
2 \\
3 \\
4 \\
5\end{array}$ & $\begin{array}{l}20 \\
0 \\
-40 \\
0 \\
20\end{array}$ & $\begin{array}{l}100 \\
1 \\
1 \\
1 \\
100\end{array}$ & 2 \\
\hline Fast cooling & $\begin{array}{l}\text { Real-time video } \\
30 \text { frames per sec }\end{array}$ & $\begin{array}{l}1 \\
2 \\
3\end{array}$ & $\begin{array}{l}20 \\
-40 \\
20\end{array}$ & $\begin{array}{l}150 \\
150 \\
150\end{array}$ & 3 \\
\hline
\end{tabular}




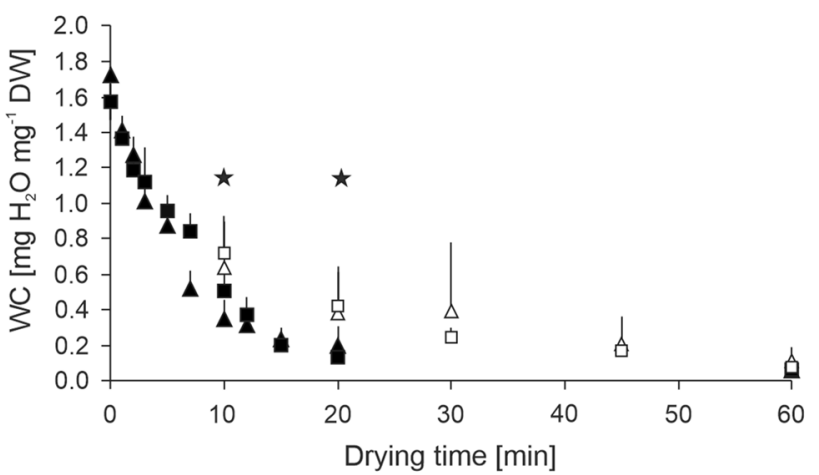

Fig. 1 Fast-drying resulted in a faster reduction in pollen water content (WC). Pollen of the wheat lines 'Ferrum' (triangles) and TRI 9102 (squares) were slow air-dried (white symbols) or fast-dried (black symbols) at room temperature at low relative humidity for up to $60 \mathrm{~min}$. Mean and standard deviation are shown for each drying time representing for 4-5 replicates each. Stars mark significant differences in WC between fast and air-dried pollen at $P<0.05$ (comparison made only for available sampling points, hereafter 10, 20, and $60 \mathrm{~min}$ of drying). The dashed line indicates WC after 5 min drying time used for following cooling experiments. DW, dry weight

This slow-drying method resulted in a wide range of pollen WCs across replicates as shown by the standard deviation, indicating an inhomogeneous drying of the pollen. The pollen grains dried on a plate, so there was probably passive drying on the surface of the pollen grains exposed to drying air at $60 \% \mathrm{RH}$. In comparison, fast-drying resulted in an averaged loss of $79.7 \%\left(0.32 \pm 0.15 \mathrm{mg} \mathrm{H}_{2} \mathrm{O} \mathrm{mg}^{-1} \mathrm{DW}\right)$ and $67.7 \%\left(0.51 \pm 0.13 \mathrm{mg} \mathrm{H}_{2} \mathrm{O} \mathrm{mg}^{-1} \mathrm{DW}\right)$ of $\mathrm{FW}$, respectively (Fig. 1), with more homogenous drying including smaller standard deviation observed. Fast-drying was carried out on pollen "floating" on a stream of $10 \% \mathrm{RH}$ dry air, which likely dried the whole grain and not just the exposed area. The loss of water during the first 10 min followed a nearlinear trend (Fig. 1) and the drying rates (slopes of linear regression curves) were significantly different between the drying approaches $(P \leq 0.001)$ but not between the wheat lines $(P=0.133)$. Fast-dried pollen lost $-0.116 \pm 0.080 \mathrm{mg}$ $\mathrm{H}_{2} \mathrm{O} \mathrm{min}^{-1}$, while air-dried pollen lost $-0.097 \pm 0.086 \mathrm{mg}$ $\mathrm{H}_{2} \mathrm{O} \mathrm{min}^{-1}$. Overall, fast-drying led to a homogenous, significant $(P \leq 0.01)$ and 1.8- and 1.4-times larger loss of water of 'Ferrum' and TRI 9102, respectively, compared to slow air-drying after $10 \mathrm{~min}$. Comparable significant differences $(P \leq 0.001)$ were also found after $20 \mathrm{~min}$ of drying (Fig. 1). However, after $60 \mathrm{~min}$, no significant differences were found in the WC of pollen from both lines exposed to air- and fastdrying, which reached steady WC values of $0.08 \pm 0.04 \mathrm{mg}$ $\mathrm{H}_{2} \mathrm{O} \mathrm{mg}{ }^{-1} \mathrm{DW}$ and $0.06 \pm 0.02 \mathrm{mg} \mathrm{H}_{2} \mathrm{O} \mathrm{mg}{ }^{-1} \mathrm{DW}$, respectively (about $95.2 \%$ WC loss from FW). In summary, the flow of dry air during fast-drying caused a larger, faster, and more homogeneous water loss on average compared to slow air-drying, particularly in the first $20 \mathrm{~min}$.
Viability of fresh pollen determined by IFC (IFC viability) was high, $93.2 \pm 5.5 \%$ and $87.3 \pm 6.7 \%$ for 'Ferrum' and TRI 9102, respectively (Fig. 2a). Pollen germination evaluated on raffinose-based media was lower, ranged between $28.8 \pm 15.3 \%$ and $38.5 \pm 19.3 \%$, respectively (Fig. 2c). After 5 min of fast-drying ( $\mathrm{WC}_{\text {'Ferrum }}=0.87 \pm 0.13$ and $\mathrm{WC}_{\mathrm{TRI} 102}=0.96 \pm 0.09 \mathrm{mg} \mathrm{H}_{2} \mathrm{O} \mathrm{mg}^{-1} \mathrm{DW}$ ), IFC viability was $83.9 \pm 6.4 \%$ and $78.8 \pm 14.2 \%$ and pollen germination was $4.5 \pm 0.9 \%$ and $10.9 \pm 1.0 \%$ for 'Ferrum' and TRI 9102, respectively. After $10 \mathrm{~min}$ of fast-drying $\left(\mathrm{WC}_{\text {'Ferrum }}=0.35 \pm 0.11\right.$ and $\mathrm{WC}_{\mathrm{TRI} 9102}=0.51 \pm 0.13 \mathrm{mg}$

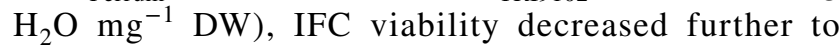
$29.6 \pm 16.3 \%$ and $49.1 \pm 15.3 \%$ for 'Ferrum' and TRI 9102, respectively, and pollen germination to $1.9 \pm 3.9 \%$ for both wheat lines. For comparison, after $10 \mathrm{~min}$ of airdrying, pollen germination of both wheat lines dropped to $12.2 \pm 12.3 \%$ (Fig. 2c), but in this case, WC was significantly higher $\left(0.68 \pm 0.22 \mathrm{mg} \mathrm{H}_{2} \mathrm{O} \mathrm{mg}{ }^{-1} \mathrm{DW}\right)$. After $60 \mathrm{~min}$ of air- and fast-drying, when WC was below $0.08 \pm 0.04$ and

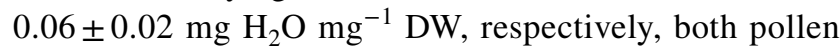
germination and IFC viability dropped to $0 \%$ (Fig. 2c,d), although after 20 min of drying, viability was near zero in both drying regimes. The decrease of viability during drying period (or the reduction of pollen WC) followed a sigmoidal trend (Fig. 2a,b). To estimate the "damaging" WC during drying, we assumed that at this point the IFC viability dropped by one-third to $66 \%$ and calculated the WCs using probit transformation. Finally, the damaging WCs were estimated at $0.83 \pm 0.11$ and $0.94 \pm 0.11 \mathrm{mg} \mathrm{H}_{2} \mathrm{O}$ $\mathrm{mg}^{-1}$ DW for 'Ferrum' and TRI 9102, respectively, during fast-drying. When pollen germination dropped by one-third, at about $20 \%$, the damaging WCs was at $1.29 \pm 0.16$ and $1.29 \pm 0.13 \mathrm{mg} \mathrm{H}_{2} \mathrm{O} \mathrm{mg}^{-1} \mathrm{DW}$ for air- and for fast-drying, respectively, indicating that damaging WCs were similar between both drying methods and wheat lines. Coefficients of correlation between WC and IFC viability or pollen germination were $0.92(P<0.001)$ and $0.94(P<0.001)$, respectively, suggesting that pollen viability is tightly linked to WC.

\section{Thermo-physical properties of wheat pollen are altered by drying procedures before ultra-low freezing}

Differential scanning calorimetry detected diverse firstand second-order phase transitions in both the cooling and warming scans of samples with varying WCs. During cooling scans, broad exothermic events (crystallization) were detected between -12 and $-56{ }^{\circ} \mathrm{C}$ for wheat pollen having WC between 0.27 and $1.77 \mathrm{mg} \mathrm{H}_{2} \mathrm{O} \mathrm{mg}$ DW. In some cooling thermograms, multiple broad crystallization peaks were observed in pollen samples dried to a maximum of $5 \mathrm{~min}$ (WC between 0.91 and $1.77 \mathrm{mg} \mathrm{H}_{2} \mathrm{O}$ 


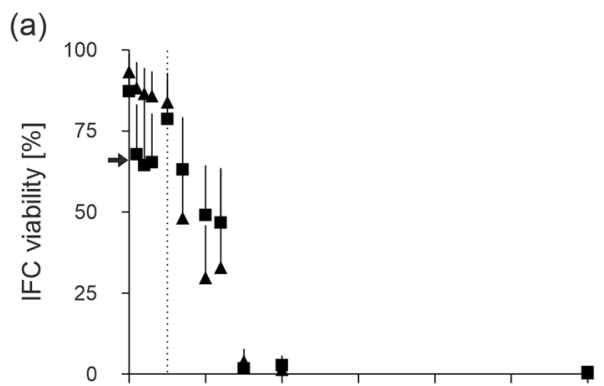

(c)

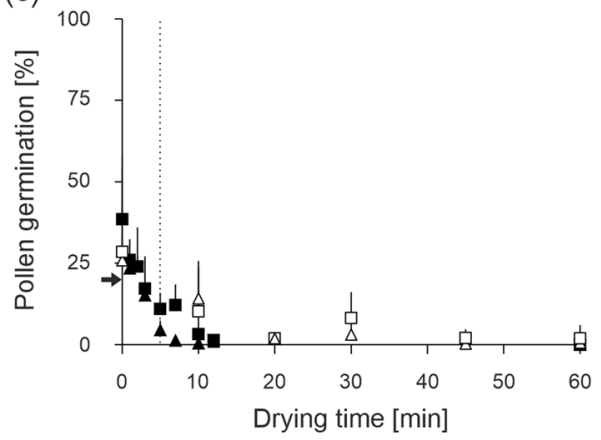

Fig. 2 Reduction in pollen water content (WC) affects pollen viability. Pollen of wheat lines 'Ferrum' (triangles) and TRI 9102 (squares) were slow air-dried (white symbols) or fast-dried (black symbols) for 1 to $60 \mathrm{~min}$. a, c Drying time and $\mathbf{b}, \mathbf{d}$ pollen WC were plotted against $(\mathbf{a}, \mathbf{b})$ pollen viability determined by impedance flow cytometry (IFC viability) and $\mathbf{c}, \mathbf{d}$ pollen germination determined on a raffinose-based medium. Mean and standard deviation are shown for each drying time and respective WCs representing 4-5 replicates each.

$\mathrm{mg}^{-1} \mathrm{DW}$ ). Additionally, a second small peak, presumably eutectic formations (Sun 2021), was found at $-100{ }^{\circ} \mathrm{C}$ and 'crystallization loops' appeared in most pollen samples with high WC $\left(>1 \mathrm{mg} \mathrm{H}_{2} \mathrm{O} \mathrm{mg}^{-1}\right.$ DW corresponding to $<5$ min fast-drying) (Supplemental figure S2). Broad endothermic events (melting transitions) during the warming program were observed between -3 to $-32{ }^{\circ} \mathrm{C}$. When the WC of fresh pollen of both wheat lines $(1.64 \pm 0.11 \mathrm{mg}$ $\mathrm{H}_{2} \mathrm{O} \mathrm{mg}^{-1} \mathrm{DW}$ ) was reduced by fast-drying for up to $15 \mathrm{~min}$ $\left(\geq 0.22 \pm 0.05 \mathrm{mg} \mathrm{H}_{2} \mathrm{O} \mathrm{mg}^{-1} \mathrm{DW}\right)$ or by air-drying for up to $60 \mathrm{~min}\left(0.08 \pm 0.02 \mathrm{mg} \mathrm{H}_{2} \mathrm{O} \mathrm{mg}{ }^{-1} \mathrm{DW}\right)$, the size of the broad crystallization and melting peaks (measured by the enthalpy $[\Delta H]$ of transition) declined, indicating that these phase transitions are ice-crystal formation and melting events (Fig. 3a).

By plotting WC against onset and peak temperature (Fig. 3b), a moderate decrease of the regression line was shown until WC dropped to $0.74 \mathrm{mg} \mathrm{H}_{2} \mathrm{O} \mathrm{mg}^{-1} \mathrm{DW}$. This would be expected for a dilute solution of increasing concentration and was observed in embryos of recalcitrant seeds (Pammenter et al. 1991). Below, a rapid decrease in the onset and peak temperatures of the water melting transitions with WC was observed, indicating a change in the
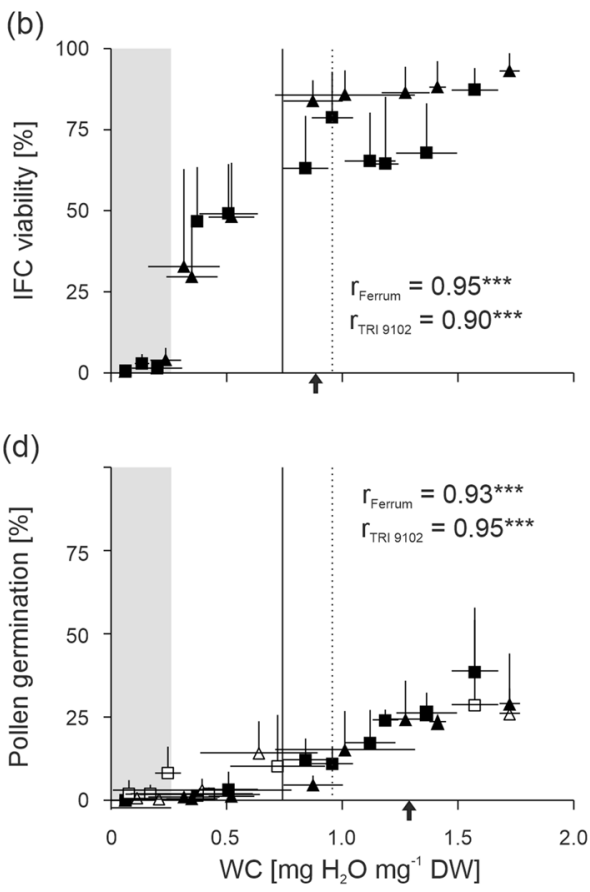

The dashed lines indicate pollen viability/germination and WCs after 5 min drying time used for following cooling experiments. Shaded areas show WCs at which no frozen water was detected. Solid lines indicate a transition of onset/peak temperatures in the melting curves (compare with Fig. 3b). Black arrows indicate damaging WC (b, d), at which IFC viability and pollen germination dropped by one-third $(\mathbf{a}, \mathbf{c})$. DW, dry weight

water properties of the cells as the solute concentration continues to increase which strongly affects the melting activity of the ice crystals. Furthermore, the $\Delta H$ of melting transitions dropped linearly (Fig. 3c) and reached $0 \mathrm{~J} \mathrm{mg}^{-1}$ DW at $<0.28 \mathrm{mg} \mathrm{H}_{2} \mathrm{O} \mathrm{mg}{ }^{-1}$ DW after more than $12 \mathrm{~min}$ fast-drying. The value for $\Delta H$ of melting (slope of linear regression) was 106.6 and $119.1 \mathrm{~J} \mathrm{mg}^{-1} \mathrm{H}_{2} \mathrm{O}$ for 'Ferrum' and TRI 9102, respectively (Fig. 3c). The amount of water that did not freeze was calculated from the intersection of the $\mathrm{X}$-axis and the sloped line drawn for water transitions. Unfrozen WCs were achieved at 0.24 and $0.28 \mathrm{mg} \mathrm{H}_{2} \mathrm{O}$ $\mathrm{mg}^{-1}$ DW for 'Ferrum' and TRI 9102, respectively. Coefficients of correlation of the regression lines constructed to calculate the unfrozen WC showed high-quality fit for 'Ferrum' $\left(r^{2}=0.97\right)$ and TRI $9102\left(r^{2}=0.95\right)$. At WCs below the unfrozen WC pollen showed very low or no viability (Fig. 2b), however, at WCs near the unfrozen WC, some pollen was still viable $(39.8 \pm 24.8 \%$ IFC viability at $<0.39 \mathrm{mg}$ $\mathrm{H}_{2} \mathrm{O} \mathrm{mg}^{-1}$ DW corresponding to 12 min drying time), indicating that under these conditions some viable pollen could be exposed to sub-zero temperatures without a lower risk of ice-crystal formation. However, to avoid over-drying of pollen when drying to WCs below the unfrozen WC, in further 
Fig. 3 Heat flow decreases when pollen water content (WC) declines and presumably causes fewer crystallization events. Pollen of wheat lines 'Ferrum' (triangles) and TRI 9102 (squares) were slow air(white symbols) and fast-dried (black symbols) for up to $60 \mathrm{~min}$ and heat flow measured using Differential Scanning Calorimetry (DSC). a Heating thermograms represent warming curves of selected replicates of pollen from wheat line 'Ferrum'. b Relationship between onset temperature (closed symbols) and peak temperatures (open symbols) of the melting transitions with WC. The dashed line indicates the WC (corresponding to $>5$ min partially fast-drying time) from which we observed a steep viability decline (compare Fig. 2a, c). c Relationship between the pollen WC and the enthalpy $(\Delta H)$ calculated on basis of the area covered by the warming curves is shown for air- and fast-dried pollen. The dashed line indicates the WC and respective enthalpy after 5 min drying time used for following cooling experiments. Shaded areas show WCs at which no frozen water was detected for both wheat lines and drying methods

freezing experiments, we applied partially fast-drying for 5 min which provided $>50 \%$ IFC viability.

\section{Partial fast-drying and fast cooling/warming may contribute to pollen survival by reducing intracellular ice-crystal formation}

Changes in structure and colour were observed in fresh and partially fast-dried pollen (with a WC above the unfrozen WC) but not in fully dried pollen (to WCs below the unfrozen WC), during both slow and fast cooling/ warming. During slow cooling, both fresh and partially fast-dried pollen suddenly 'flashed' and turned dark at $-31.6 \pm 1.0{ }^{\circ} \mathrm{C}$ and $-38.0 \pm 0.8^{\circ} \mathrm{C}$, respectively. The so-called 'darkening' was followed by the formation of ice crystal on the surface of the pollen grains (Figs. 4a, b, 5a, Supplemental video 1-2). During slow warming, pollen turned completely black at $-32.4 \pm 6.1{ }^{\circ} \mathrm{C}$ and $-31.5 \pm 1.7^{\circ} \mathrm{C}$, respectively, and thawing of ice crystals began at $-12.6 \pm 4.0^{\circ} \mathrm{C}$ for fresh pollen and at $-17.6 \pm 1.2{ }^{\circ} \mathrm{C}$ for partially fast-dried pollen. At the end of the program, fresh pollen shrunk massively and had an IFC viability of $0.9 \pm 0.7 \%$, while the partially fast-dried pollen also shrunk, but had an IFC viability of $4.5 \pm 7.0 \%$. During fast cooling, less and/or smaller ice crystals were observed around the pollen. Darkening occurred in both fresh and partially fast-dried pollen, when temperature was hold at $-40{ }^{\circ} \mathrm{C}$ for $3 \mathrm{~min}$ and turned completely black at $-19.6 \pm 11.6{ }^{\circ} \mathrm{C}$ and $-18.6 \pm 5.0{ }^{\circ} \mathrm{C}$ during fast warming, respectively (Fig. 4a,b, 5b, Supplemental video 3-4). At the end of the fast warming step, fresh pollen and partially fast-dried pollen appeared rounder were less dehydrated and showed some viability (but not germination) (fresh pollen: $1.5 \pm 1.7 \%$, partially fast-dried pollen: $6.1 \pm 8.8 \%$ ) compared to slow cooling/warming (Fig. 6). In addition, the change in colour and thawing of
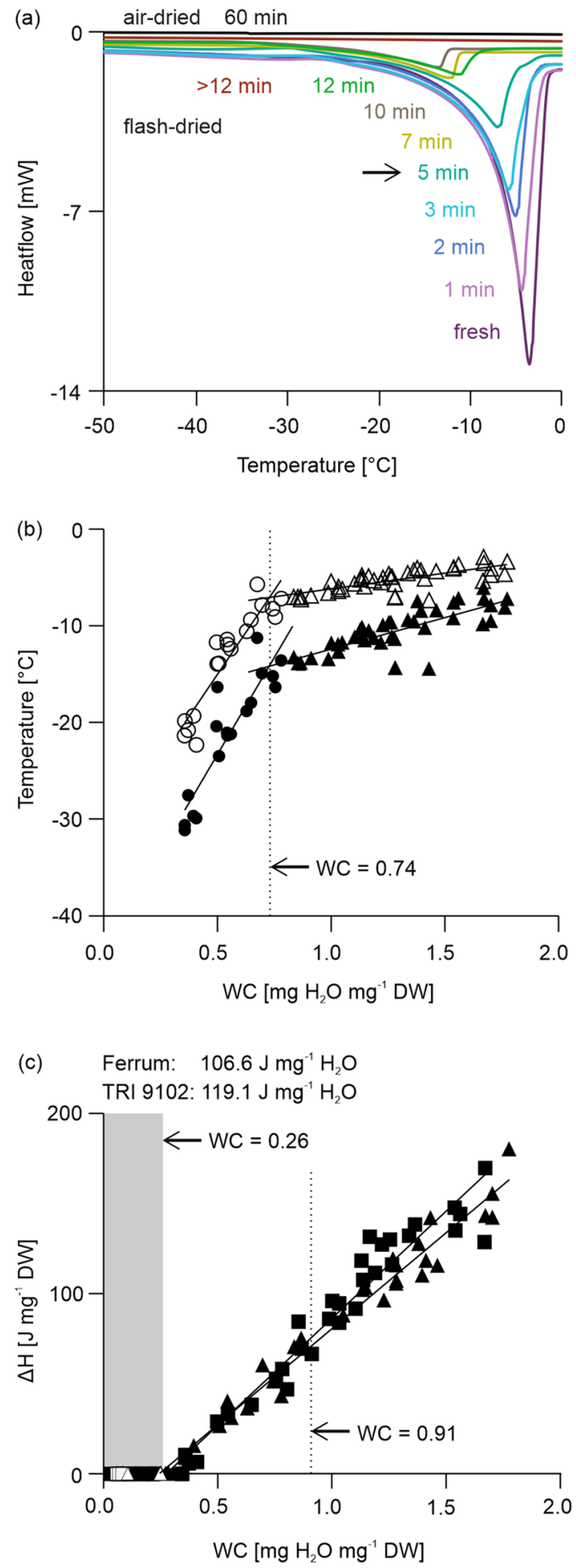

ice crystals (fresh pollen: $-6.0 \pm 8.8{ }^{\circ} \mathrm{C}$, partially fastdried pollen: $-4.9 \pm 4.6{ }^{\circ} \mathrm{C}$ ) occurred at about $10{ }^{\circ} \mathrm{C}$ higher temperatures compared with slow cooling/warming (Fig. 5b). Pollen dried below the unfrozen WC had 

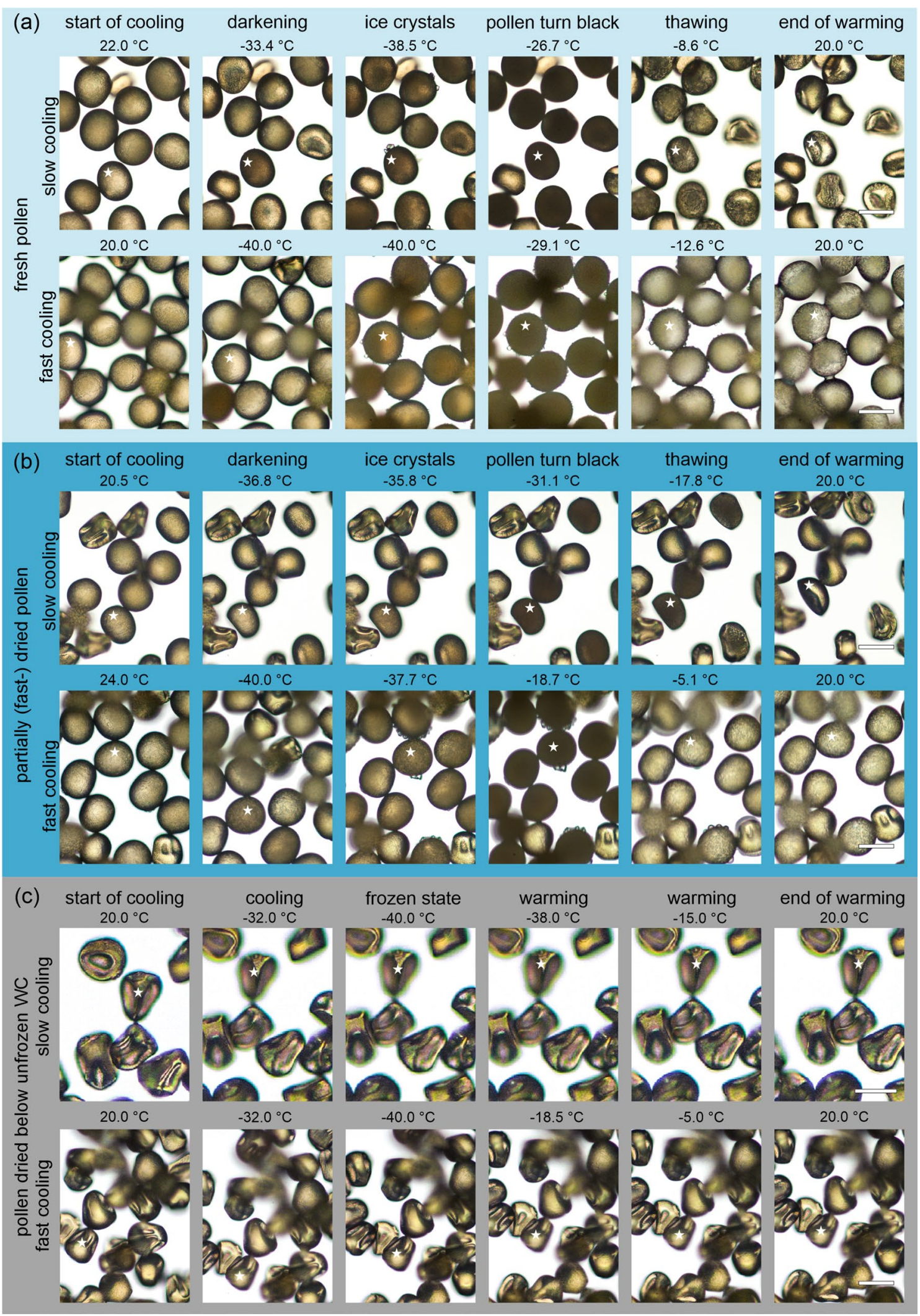
4Fig. 4 Slow and fast cooling/warming combined with various drying treatments infers a variation in the structural changes in wheat pollen that occur at different temperatures. a Fresh pollen (light blue panel), b pollen partially fast-dried for 5 min (dark blue panel), and c pollen air-dried to WCs below the unfrozen WC for 60 min (grey panel) of wheat line TRI 3633 were cooled and warmed at $1{ }^{\circ} \mathrm{C} \mathrm{min}-1$ (slow cooling) and $150{ }^{\circ} \mathrm{C} \mathrm{min}^{-1}$ (fast cooling). Significant events (i.e., darkening, surface ice crystallization, pollen turn black, and thawing) were visualized by extracting images from the videos in Supplementary video S1 to S6; the range of temperatures is shown in Fig. 5. Due to movements in the Linkam chamber, for better orientation, we marked the same pollen in each series (row) with a star. Scale bars indicate $50 \mu \mathrm{m}$, size and magnification were identical for all images

an IFC viability of $0 \%$ (Fig. 2) and showed no darkening or ice-crystal formation at either slow or fast cooling (Fig. 4c, Supplemental video 5-6). Overall, pollen treated with a combination of partially fast-drying and fast cooling/warming tend to have visually less and/or smaller ice crystals that may support pollen survival.

\section{Discussion}

The preservation of wheat pollen is important for conventional breeding, hybrid breeding and production and the conservation of wheat genetic diversity. Currently, any prolonged storage, more than several hours, is not possible due to the high desiccation sensitivity of mature pollen after shedding. In this paper, we investigated how drying rate and cooling/warming rate affect pollen viability and the physicochemical properties of the water in their cells. We found that viability in pollen was lost soon during the drying process, even before any changes in the structural properties of water are detected by DSC. However, about $40 \%$ of wheat pollen retained viability at WCs $>0.28 \mathrm{mg} \mathrm{H}_{2} \mathrm{O} \mathrm{mg}{ }^{-1} \mathrm{DW}$, a WC slightly above the limit at which ice freezing/melting events occur. At this WC, pollen grains appear to have highly concentrated cytoplasm based on the thermal responses of the freezing water, which open the option for the development of successful ultra-low-temperature storage. We also measured that the combination of fast-drying, fast cooling, and warming rates during video-cryomicroscopy resulted in a reduction and delay of ice-crystal formation, a reduction of the temperature for intracellular water crystallization, and an increase in the temperature of intracellular ice melting. All three properties may favour the formation of intracellular glasses and could contribute to the success of wheat pollen cryopreservation; however, a fine-tuning of the combination of fast partial-drying and cooling rates is needed to achieve higher survival/germination rates.

\section{Desiccation damages prior cooling can be reduced by rapid drying}

Dependent on the drying rate and the amount of water removed, different types of damages compromise survival in desiccation-sensitive pollen and tissues (Pammenter and Berjak 2014). At high WC, dehydration causes physical damages by reducing cell volume (Pammenter and Berjak 2014). In wheat, we observed some shrinkage of the pollen grains when the pollen population was dried to $0.91 \pm 0.11 \mathrm{mg} \mathrm{H}_{2} \mathrm{O} \mathrm{mg}^{-1}$ DW (Fig. 4b). Further intense drying causes "desiccation damage sensu stricto" (Walters et al. 2001). The WC at which $33 \%$ of the initial wheat pollen viability is lost was estimated at between $0.83 \pm 0.11$ and $1.29 \pm 0.16 \mathrm{mg} \mathrm{H}_{2} \mathrm{O} \mathrm{mg}^{-1}$ DW depending on the viability testing method used. We considered these WC ranges to be an indication of the WC limit at which the pollen was significantly damaged and refer to them as damaging WC. Compared to embryonic axes of recalcitrant seeds that retain high viability (over 90\%) upon drying to near freezable WCs at $\sim 0.25-0.50 \mathrm{mg} \mathrm{H}_{2} \mathrm{O} \mathrm{mg}^{-1} \mathrm{DW}$ (Wesley-Smith et al. 2001a, b), the damaging WC limit determined for wheat pollen in the current study was very high. By contrast, maize pollen dried to $0.55 \mathrm{mg} \mathrm{H}_{2} \mathrm{O} \mathrm{mg}{ }^{-1}$ DW can still retain over $75 \%$ germination (Buitink et al. 1996). In wheat pollen, the damaging WC determined fell above the break in the relation between $\mathrm{WC}$ and water melting peak/onset temperature (Fig. 3b) detected at $0.74 \mathrm{mg} \mathrm{H}_{2} \mathrm{O} \mathrm{mg}^{-1}$ DW. Although conjectural, this break might be due to a change in the water properties of the cytoplasm that could be related to a threshold in the concentration of solutes during drying that alter the physicochemical properties of ice-crystal formation (Berjak et al. 1993) and may lead to deleterious molecular interactions (Oliver et al. 2020). When WC is reduced below a critical value, the removal of water from macromolecular and membrane surfaces causes metabolism-linked damages (Pammenter and Berjak 2000). In wheat, pollen lost most of its initial viability around freezable WC at $<0.28 \mathrm{mg} \mathrm{H}_{2} \mathrm{O}$ $\mathrm{mg}^{-1} \mathrm{DW}, \sim 13 \% \mathrm{FW}$ basis. Extensive membrane damages were found in desiccation-sensitive pollen of Pennisetum typhoides and maize dried to $3 \%$ and 7 to $8 \% \mathrm{WC}$, respectively (Hoekstra et al. 1989; Kerhoas et al. 1987). In wheat pollen, at WC below $0.06 \mathrm{mg} \mathrm{H}_{2} \mathrm{O} \mathrm{mg}^{-1} \mathrm{DW}$ (2.4\%), viability was completely lost and accompanied with the strong shrinkage of wheat pollen (Fig. 4c). At this stage, cells, organelles, and membranes may collapse (Buitink et al. 1998) resulting in cell/pollen death (Bajaj 1985; Pammenter and Berjak 2000; Pammenter et al. 2003).

However, drying damage is considered to be avoided depending on the drying rate. When drying is conducted slowly, electron transfer in mitochondria and plastids is impaired that facilitates the formation of reactive oxygen species (ROS) (Halliwell and Gutteridge 2015; Hendry 
(a)

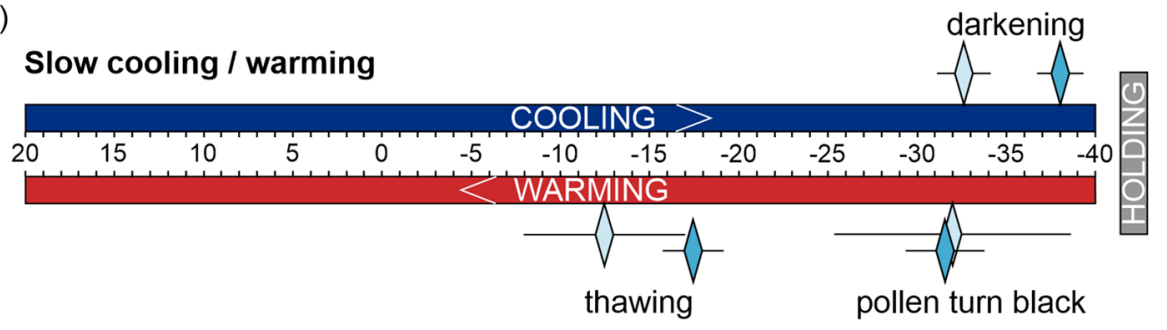

(b)

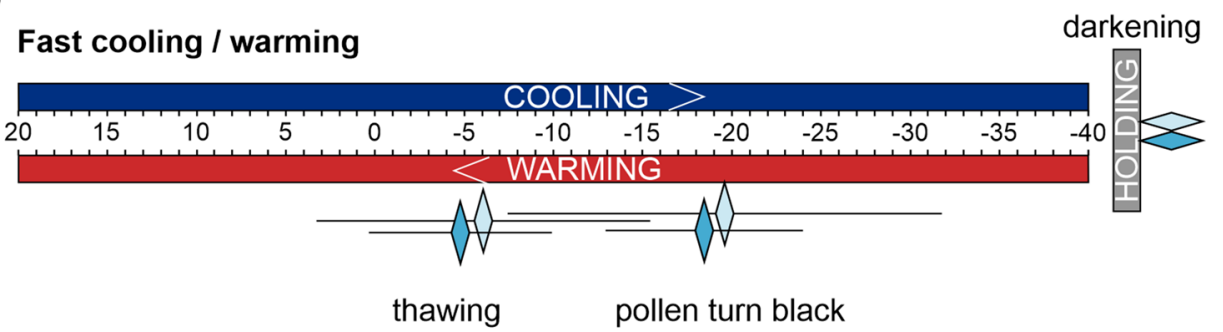

Fig. 5 Cooling/warming rate and pollen water content affect crystallization and melting events. Fresh pollen (light blue diamonds) and pollen partially fast-dried for $5 \mathrm{~min}$ (petrol blue diamonds) of the wheat line TRI 3633 were used to evaluate the significant events during a slow cooling/warming at $1{ }^{\circ} \mathrm{C} \mathrm{min}-1$ and b fast cooling/ warming at $150{ }^{\circ} \mathrm{C} \mathrm{min}^{-1}$. Temperature ranges (diamonds and lines) are given for significant structural changes of the pollen (darken-

et al. 1992; Smirnoff 1993) reacting with proteins, lipids, and nucleic acids (Halliwell and Gutteridge 2015). Additionally, the reduced fluidity of the cytoplasm at intermediate WC limits the efficiency of corresponding detoxifying processes (Bailly 2004; Berjak 2006; Vertucci and Farrant 1995). When drying is conducted sufficiently rapid, i.e., by a stream of dry air (Buitink et al. 1996), and WC in dehydration-sensitive cells remain above the critical points, the time in which cells pass through intermediate WC ranges is shorter. Thus, fast-drying may reduce the overall occurrence of metabolism-derived damages (Farrant et al. 1993; Kioko et al. 1998; Pammenter and Berjak 1999; Pammenter et al. 2002; Pritchard and Manger 1998). However, despite the faster and more homogeneous drying induced by the fast-drying method applied in this work (Fig. 1), we found that both the damaging WC calculated by the viability/WC relations (Fig. 2) or the viability loss observed at given WCs was comparable for the air- and fast-drying methods used, suggesting that the different drying rates applied in this study were not sufficient to detect drying-related differences in viability prior to the cooling stage. Nonetheless, fast-drying reduces the time the pollen is exposed to stressful metabolic processes. Due to the additional stress on the pollen by cooling, we think that fast-drying prior cooling increases the chances that the desiccation-sensitive wheat pollen will survive the whole cryopreservation process. ing, pollen turn black, thawing) exposed to different cooling/warming approaches. Diamonds and horizontal lines represent means and standard deviations of 5 biological replicates for each condition. For fast cooling/warming and due to the high cooling rate, means and standard deviations were interpolated based on temperature at the start, within the holding phase, and at the end of the cooling/warming program and a few temperature points in between

\section{Wheat pollen can partly survive the loss of freezable water}

When cells lose the unbound, freezable water, intracellular viscosity increases (Hoekstra et al. 2001). Upon further drying and/or cooling, the fluid cytoplasm develops properties of a solid structure (Ballesteros and Walters 2007, 2011; Buitink and Leprince 2004) which is non-crystalline (unlike the intracellular ice that forms in the presence of freezable water) and is referred to as a glass. A glass is an amorphous solid that combines properties of a solid and a liquid without any defined structures (Buitink and Leprince 2004). The increase in cytoplasmic viscosity correlates with decreases in molecular mobility (Ballesteros and Walters 2011; Leprince and Hoekstra 1998; Sun 2000) and metabolic activity where most chemical reactions are ceased (Benson 2008). The extremely high cytoplasmic viscosity of the glass and the binding of most water molecules to macromolecules prevent the formation of ice crystals during cooling (Benson 2004). For diverse pollen, ice crystallization events are not detected by DSC typically at WC $<20 \%\left(0.21-0.26 \mathrm{mg} \mathrm{H}_{2} \mathrm{O}\right.$ $\left.\mathrm{mg}^{-1} \mathrm{DW}\right)$. Below this WC, cryo-injuries can be prevented during freezing and thawing (Dinato et al. 2020). For wheat pollen, we demonstrated that depending on the drying rate, pollen reduced the fraction of freezable water in less than $30 \mathrm{~min}$, but viability was severely impaired, when pollen dried to the freezable WC at $<0.28 \mathrm{mg} \mathrm{H}_{2} \mathrm{O} \mathrm{mg}^{-1} \mathrm{DW}, \sim 13 \%$ 

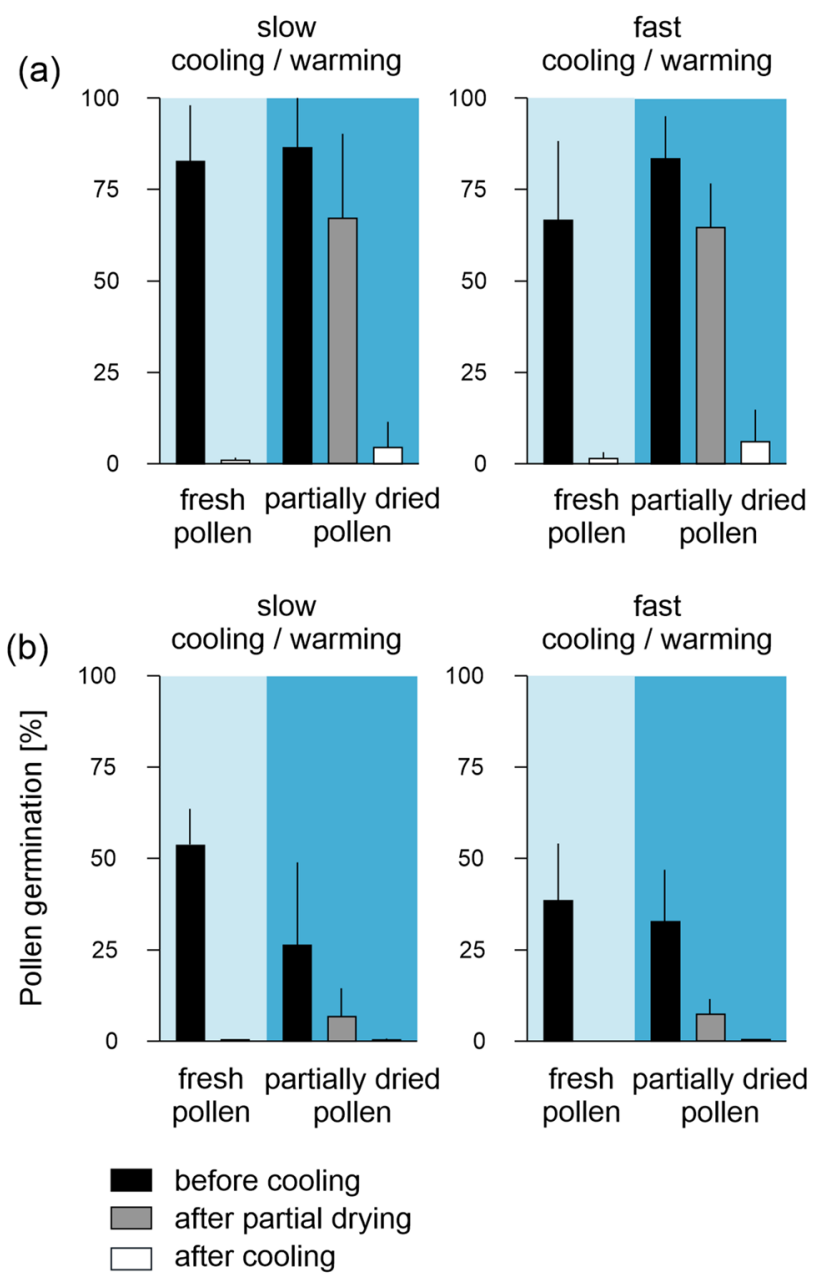

Fig. 6 Partial fast-drying increases the chance of pollen survival after cooling/warming. Fresh pollen (black bars), and pollen fastdried for 5 min (grey bars) of the wheat line TRI 3633 was exposed to slow cooling/warming at $1{ }^{\circ} \mathrm{C} \mathrm{min}{ }^{-1}$ and fast cooling/warming at $150{ }^{\circ} \mathrm{C} \mathrm{min}^{-1}$. Pollen viability was analysed by a Impedance Flow Cytometry (IFC viability) and $\mathbf{b}$ as pollen germination on a raffinosebased media before (black bars), after fast-drying (grey bars) and after cooling (white bars). Bars and lines show means and standard deviations of 5 biological replicates

FW basis. However, slightly above the freezable WC limit, wheat partially fast-dried pollen retained IFC viability at $39.8 \pm 24.8 \%$. Although both, desiccation-sensitive and -tolerant, plant tissues are capable of forming glasses upon drying and/or cooling (Buitink et al. 1996), most dehydration-sensitive plant material cannot survive the low WC at which glasses typically form before exposing the samples to sub-zero temperatures (Berjak and Pammenter 2004; Berjak and Pammenter 2004). Nevertheless, cryopreservation was successfully implemented for desiccation-sensitive maize pollen. Dependent on genotype, some varieties retained high viability and seed set after drying to between 12 and $20 \%$ WC corresponding to 0.14 and $0.25 \mathrm{mg} \mathrm{H}_{2} \mathrm{O} \mathrm{mg}^{-1} \mathrm{DW}$
(Barnabás and Rajki 1976, 1981). Inagaki and Mujeeb-Kazi (1994) achieved about $22.1 \%$ of maize pollen germination after storage at $-80^{\circ} \mathrm{C}$ and $9.5 \%$ WC for 4 weeks which was likely due to the removal of the freezable water fraction and the formation of a glassy state below $-25^{\circ} \mathrm{C}$ at such WCs (Buitink et al. 1996). To cryopreserve desiccation-sensitive wheat pollen with high viability, existing procedures (Nebot et al. 2021) must be modified to favour the formation of a glassy state while overcoming the constraints of the low viability when WC is reduced below the freezable WC limit. This balance between vitrification without ice formation may be achieved by modulating cooling rates at the WCs at which wheat pollen still retains high viability.

\section{Fast cooling limits and delays ice-crystal formation compared to slow cooling}

The survival of plant cells after freezing is dependent on the lethal effects of intracellular ice. Ice crystals affect the organization of the cytoplasm and damage the membranes of cell organs by increasing their volume (Wolkers and Oldenhof 2021). The formation of intracellular ice can be effectively minimized by the cooling rate (Mazur 2004). At very slow cooling rates $\left(\sim 0.1\right.$ to $\left.5{ }^{\circ} \mathrm{C} \mathrm{min}^{-1}\right)$, ice is formed intercellularly. The chemical potential between cells inside and outside leads to water efflux, cell dehydration (Wolkers and Oldenhof 2021), and eventually vitrification of the cytoplasm. However, the dehydration during slow cooling may severely damage desiccation-sensitive cells (Wesley-Smith et al. 2001a, b). When the cooling rate increases $\left(\sim 100{ }^{\circ} \mathrm{C} \mathrm{min}-1\right)$, the time for the water to flow out the cell is not sufficient to prevent supercooling, spontaneous intracellular freezing, and the aggregation of larger ice crystals (Mazur 1984). At very high cooling rates $\left(>1000^{\circ} \mathrm{C} \mathrm{min}^{-1}\right)$, more, smaller and evenly distributed ice crystals appear (Dumont et al. 2003) and might be more beneficial for desiccation-sensitive cells compared to dehydration at slower cooling rates. Therefore, in desiccationsensitive embryonic axes of Aesculus hippocastanum L., a combination of fast-drying followed by cooling at very high rates reduced deteriorative processes and enabled the survival of the tissue (Wesley-Smith et al. 2001a, b). When wheat pollen was fast-dried for $5 \mathrm{~min}$ and rapidly cooled and warmed in the Linkam chamber using $150{ }^{\circ} \mathrm{C} \mathrm{min}-1$ (Fig. 3, Supplemental videos 2,3), we observed a reduction of intracellular ice crystals formation and the limitation of the ice-crystal formation to the isothermal step at $-40{ }^{\circ} \mathrm{C}$. Under these conditions, some wheat pollen still showed IFC viability of $6.1 \pm 8.8 \%$. To observe processes of ice formation in wheat pollen by cryomicroscopy, we were limited to the rapid cooling rates at $\max 150{ }^{\circ} \mathrm{C} \mathrm{min}^{-1}$ and an experimental design conceived to study ice formation in the first stages of cooling. However, higher very rapid 
cooling rates to $<-130{ }^{\circ} \mathrm{C}$ temperatures should be applied in future experiments to combine the effects of fast-drying, evenly distributed ice crystals, and the supercooling of the system which may allow the formation of a glassy state and an even higher survival after cryopreservation.

During cryomicroscopy, a sudden change in opacity of the cytoplasm is often described as "blackening" or "flashing" (Acharya and Devireddy 2010; Day et al. 2000; Scheiwe and Korber 1984; Smith and Smiles 1953). The cause for blackening is not completely understood. It may occur as a result of light scattering from the surfaces of ice crystals (Körber et al. 1991; Smith 1961), from tiny gas bubbles formed in parallel (Steponkus and Dowgert 1981) or from rearrangement and aggregation of the intracellular organic matter (Dong et al. 2010; Stott and Karlsson 2009). Mazur et al. (2005) speculated that the darkening is the result of glass transition of intracellular water. In wheat pollen studied, a 'darkening' appeared before ice crystals were visible and indicate that ice crystals alone or combined with vitrification events may be the cause of this change in opacity in fresh and fast-dried pollen (Fig. 4a,b, Supplemental videos 1, 2). Interestingly, an abruptly second darkening termed 'blackening' or 'pollen turn black' occurred during warming. This phenomenon was also observed in mouse embryos and was suggested to be related with devitrification, but more likely with re-crystallization events of small intracellular crystals (Mazur et al. 2005). In general, cooling and warming rates are intertwined (Pegg 2007) and both processes affect the viability (Normah and Makeen 2008). During re-crystallization, ice crystals merge and damage the cells (Mazur 1984; Meryman 1966). However, there was a clear difference in the temperature at which the 'darkening' and 'pollen turn black' occurred between slow and fast cooling/warming and between fresh- and fast-dried pollen. Here, we speculate that at slower cooling/warming and at higher WCs, ice crystals had more time and volume to aggregate which facilitated an earlier 'darkening' and 'blackening' compared to fast cooling/warming and fast-drying. Nonetheless, these effects on the delay of ice-crystal formation did not favour a higher survival of the pollen grains. In further experiments, it has to be clarified if the 'darkening' and/or 'blackening' of cells is related with pollen viability changes and could be used to optimize the cryogenic procedure for wheat pollen preservation.

\section{Conclusion}

Wheat is among the most important crops worldwide and the preservation of viable pollen would be beneficial for breeding programs. By analysing the change in pollen viability after exposure to different drying treatments, we observed that wheat pollen lost viability extremely fast (after $>12$ min drying) and that the increased drying rate did not show the expected benefits. However, when fast-dried pollen was exposed to fast cooling/warming rates, we found some viable pollen, a reduction of the ice crystallization temperature, and a lower amount of ice crystals formed. Nevertheless, these results were not enough to achieve a high pollen survival. Long-term wheat pollen storage is still not efficient due to its extreme sensitivity to the removal of water molecules and osmotic concentration. Further investigations of the water properties of wheat pollen at high WCs, a better control of the ice crystallization and re-crystallization events during freezing and warming, and a better understanding of the vitrification of pollen at high water contents will help to develop more optimal cryopreservation protocols. Thereby, it should be considered that cooling/warming procedures should be extremely fast at WCs where viability is high and, eventually, cryoprotective chemicals, if entered, may stabilize the pollen without ice formation. These protocols and further testing in the fertilization of plants with cryopreserved pollen will elucidate if wheat pollen cryogenic storage can be an efficient tool for wheat conservation and breeding.

Supplementary Information The online version contains supplementary material available at https://doi.org/10.1007/s00299-021-02819-w.

Acknowledgements We like to acknowledge Kerstin Wolf, Jürgen Marlow, and the gardeners of IPK and Kew garden/Wakehurst for their excellent technical support.

Author contribution statement DI, DB, and MN conceived and designed research. DI conducted experiments and wrote the first draft of the manuscript. All authors commented on previous versions and approved the final manuscript.

Funding Open Access funding enabled and organized by Projekt DEAL. The work is part of a $\mathrm{PhD}$ project and was supported by Leibniz Institute of Plant Genetics and Crop Plant Research (IPK). The Royal Botanic Gardens, Kew receives grant-in-aid from Defra.

Data availability The datasets generated during and/or analysed during the current study are available from the corresponding author on reasonable request.

Code availability Not applicable.

\section{Declarations}

Conflict of interest The authors have no conflicts of interest to declare that are relevant to the content of this article.

Ethical approval Not applicable.

Consent to participate Not applicable

Consent for publication Not applicable

Open Access This article is licensed under a Creative Commons Attribution 4.0 International License, which permits use, sharing, adaptation, distribution and reproduction in any medium or format, as long as you give appropriate credit to the original author(s) and the source, 
provide a link to the Creative Commons licence, and indicate if changes were made. The images or other third party material in this article are included in the article's Creative Commons licence, unless indicated otherwise in a credit line to the material. If material is not included in the article's Creative Commons licence and your intended use is not permitted by statutory regulation or exceeds the permitted use, you will need to obtain permission directly from the copyright holder. To view a copy of this licence, visit http://creativecommons.org/licenses/by/4.0/.

\section{References}

Acharya T, Devireddy RV (2010) Cryomicroscopic investigations of freezing processes in cell suspensions. Open Biotechnol J 4:2635. https://doi.org/10.2174/1874070701004010026

Alba V, Bisignano V, Alba E, De Stradis A, Polignano GB (2011) Effects of cryopreservation on germinability of olive (Olea europaea L.) pollen. Genet Resour Crop Ev 58:977-982. https://doi. org/10.1007/s10722-011-9736-z

Bailly C (2004) Active oxygen species and antioxidants in seed biology. Seed Sci Res 14:93-107. https://doi.org/10.1079/ssr2004159

Bajaj YPS (1985) Cryopreservation of embryos. In: Kartha KK (ed) Cryopreservation of plant cells and organs. CRC Press Inc., Boca Raton, pp 227-267

Ballesteros D, Walters CT (2007) Calorimetric properties of water and triacylglycerols in fern spores relating to storage at cryogenic temperatures. Cryobiology 55:1-9. https://doi.org/10.1016/j.cryobiol. 2007.03.006

Ballesteros D, Walters C (2011) Detailed characterization of mechanical properties and molecular mobility within dry seed glasses: relevance to the physiology of dry biological systems. Plant J 68:607-619. https://doi.org/10.1111/j.1365-313X.2011.04711.x

Ballesteros D, Sershen VB, Berjak P, Pammenter NW (2014) Uneven drying of zygotic embryos and embryonic axes of recalcitrant seeds: challenges and considerations for cryopreservation. Cryobiology 69:100-109. https://doi.org/10.1016/j.cryobiol.2014.05.010

Barnabás B, Rajki E (1976) Storage of maize (Zea mays L.) pollen at $-196^{\circ} \mathrm{C}$ in liquid nitrogen. Euphytica 25:747-752. https://doi.org/ 10.1007/Bf00041614

Barnabás B, Rajki E (1981) Fertility of deep-frozen maize (Zea mays L.) pollen. Ann Bot-Lond 48:861-864. https://doi.org/10.1093/ oxfordjournals.aob.a086193

Benson EE (2004) Cryoconserving algal and plant diversity: historical perspectives and future challenges. In: Fuller BJ, Lane N, Benson EE (eds) Life in the frozen state. CRC Press, London, UK, pp 299-328

Benson EE (2008) Cryopreservation of phytodiversity: a critical appraisal of theory and practice. Crit Rev Plant Sci 27:141-219. https://doi.org/10.1080/07352680802202034

Berjak P (2006) Unifying perspectives of some mechanisms basic to desiccation tolerance across life forms. Seed Sci Res 16:1-15. https://doi.org/10.1079/Ssr2005236

Berjak P, Pammenter NW (2004) Recalcitrant seeds. In: BenechArnold RL, Sanchez RA (eds) Handbook of seed physiology: applications to agriculture. Haworth, New York, pp 305-345

Berjak P, Vertucci CW, Pammenter NW (1993) Effects of developmental status and dehydration rate on characteristics of water and desiccation-sensitivity in recalcitrant seeds of Camellia sinensis. Seed Sci Res 3:155-166. https://doi.org/10.1017/S096025850 0001732

Brewbaker JL (1967) The distribution and phylogenetic significance of binucleate and trinucleate pollen grains in the angiosperms. Am J Bot 54:1069-1083. https://doi.org/10.1002/j.1537-2197. 1967.tb10735.x
Buitink J, Leprince O (2004) Glass formation in plant anhydrobiotes: survival in the dry state. Cryobiology 48:215-228. https://doi.org/ 10.1016/j.cryobiol.2004.02.011

Buitink J, Walters-Vertucci C, Hoekstra FA, Leprince O (1996) Calorimetric properties of dehydrating pollen (analysis of a desiccationtolerant and an intolerant species). Plant Physiol 111:235-242. https://doi.org/10.1104/pp.111.1.235

Buitink J, Walters CT, Hoekstra FA, Crane J (1998) Storage behavior of Typha latifolia pollen at low water contents: interpretation on the basis of water activity and glass concepts. Physiol Plant 103:145153. https://doi.org/10.1034/j.1399-3054.1998.1030201.x

Connor KF, Towill LE (1993) Pollen-handling protocol and hydration/ dehydration characteristics of pollen for application to long-term storage. Euphytica 68:77-84. https://doi.org/10.1007/bf00024157

D’Souza L (1970) Untersuchungen über die Eignung des Weizens als Pollenspender bei der Fremdbefruchtung, verglichen mit Roggen, Triticale und Secalotricum. Zeitschrift Für Pflanzenzüchtung 63:246-269

Day JG, Fleck RA, Benson EE (2000) Cryopreservation-recalcitrance in microalgae: novel approaches to identify and avoid cryo-injury. J Appl Phycol 12:369-377. https://doi.org/10.1023/A:1008107229 005

Diller KR, Cravalho EG (1971) A cryomicroscope for the study of freezing and thawing processes in biological cells. Cryobiology 7:191-199. https://doi.org/10.1016/0011-2240(70)90021-0

Dinato NB, Imaculada Santos IR, Zanotto Vigna BB, de Paula AF, Fávero AP (2020) Pollen cryopreservation for plant breeding and genetic resources conservation. CryoLetters 41:115-127

Dong J, Malsam J, Bischof JC, Hubel A, Aksan A (2010) Spatial distribution of the state of water in frozen mammalian cells. Biophys $\mathbf{J}$ 99:2453-2459. https://doi.org/10.1016/j.bpj.2010.08.035

Dumont F, Marechal P-A, Gervais P (2003) Influence of cooling rate on Saccharomyces cerevisiae destruction during freezing: unexpected viability at ultra-rapid cooling rates. Cryobiology 46:33-42. https://doi.org/10.1016/S0011-2240(02)00161-X

Fahy GM, Wowk B (2015) Principles of cryopreservation by vitrification. In: Wolkers WF, Oldenhof $\mathrm{H}$ (eds) Cryopreservation and freeze-drying protocols. Springer, New York, pp 21-82

Farrant JM, Berjak P, Pammenter NW (1993) Studies on the development of the desiccation-sensitive (recalcitrant) seeds of Avicennia marina (Forssk.) Vierh.: the acquisition of germinability and response to storage and dehydration. Ann Bot-Lond 71:405-410. https://doi.org/10.1006/anbo.1993.1051

Franchi GG, Nepi M, Dafni A, Pacini E (2002) Partially hydrated pollen: taxonomic distribution, ecological and evolutionary significance. Plant Syst Evol 234:211-227. https://doi.org/10.1007/ s00606-002-0221-1

Ganeshan S, Rajasekharan PE, Shashikumar S, Decruze W (2008) Cryopreservation of pollen. In: Reed BM (ed) Plant cryopreservation: a practical guide. Springer Science and Business Media, Corvallis, USA, pp 443-464

Gaudet D, Yadav NS, Sorokin A, Bilichak A, Kovalchuk I (2020) Development and optimization of a germination assay and longterm storage for Cannabis sativa pollen. Plants 9:665. https://doi. org/10.3390/plants9050665

Geng X, Qiu J, Okubo H (2013) Changes of carbohydrate content during Lilium and Gladiolus pollen cryopreservation. Grana 52:202206. https://doi.org/10.1080/00173134.2013.819033

Halliwell B, Gutteridge JM (2015) Free radicals in biology and medicine. Oxford University Press, USA

Hanna WW (1990) Long-term storage of Pennisetum glaucum (L.) R. Br. Pollen. Theoret Appl Genetics 79:605-608. https://doi.org/ 10.1007/BF00226872

Hecker RJ, Stanwood PC, Soulis CA (1986) Storage of sugarbeet pollen. Euphytica 35:777-783. https://doi.org/10.1007/BF00028585 
Hendry GA, Finch-Savage W, Thorpe PC, Atherton NM, Buckland SM, Nilsson KA, Seel WE (1992) Free radical processes and loss of seed viability during desiccation in the recalcitrant species Quercus robur L. New Phytol 122:273-279. https://doi.org/10. 1111/j.1469-8137.1992.tb04231.x

Hoekstra FA, Crowe LM, Crowe HJ (1989) Differential desiccation sensitivity of corn and Pennisetum pollen linked to their sucrose contents. Plant Cell Environ 12:83-91. https://doi.org/10.1111/j. 1365-3040.1989.tb01919.x

Hoekstra FA, Golovina EA, Buitink J (2001) Mechanisms of plant desiccation tolerance. Trends Plant Sci 6:431-438. https://doi.org/ 10.1016/s1360-1385(01)02052-0

Impe D, Reitz J, Köpnick C, Rolletschek H, Börner A, Senula A, Nagel M (2020) Assessment of pollen viability for wheat. Front Plant Sci 10:1588. https://doi.org/10.3389/fpls.2019.01588

Inagaki M, Mujeeb-Kazi A (1994) Storage of maize pollen for use in haploid production of hexaploid wheat. Jpn J Breeding 44:387390. https://doi.org/10.1270/jsbbs1951.44.387

Karlsson JO (2015) Measurement of intracellular ice formation kinetics by high-speed video cryomicroscopy. Methods Mol Biol 1257:181-227. https://doi.org/10.1007/978-1-4939-2193-5_7

Kerhoas C, Gay G, Dumas C (1987) A multidisciplinary approach to the study of the plasma membrane of Zea mays pollen during controlled dehydration. Planta 171:1-10. https://doi.org/10. 1007/BF00395062

Kioko J, Berjak P, Pammenter N, Watt M, Wesley-Smith J (1998) Desiccation and cryopreservation of embryonic axes of Trichilia dregeana Sond. CryoLetters 19:5-14

Körber C, Englich S, Rau G (1991) Intracellular ice formation: cryomicroscopical observation and calorimetric measurement. J Microsc 161:313-325. https://doi.org/10.1111/j.1365-2818. 1991.tb03092.x

Leprince O, Hoekstra FA (1998) The responses of cytochrome redox state and energy metabolism to dehydration support a role for cytoplasmic viscosity in desiccation tolerance. Plant Physiol 118:1253-1264. https://doi.org/10.1104/pp.118.4.1253

Maryam, Jaskani JM, Naqvi SA (2017) Storage and viability assessment of date palm pollen. In: Al-Khayri J, Jain S, Johnson DV (eds) Methods mol biol. Humana Press, New York, NY, pp 3-13

Mazur P (1984) Freezing of living cells: mechanisms and implications. Am J Physiol-Cell Ph 247:C125-C142. https://doi.org/ 10.1152/ajpcell.1984.247.3.C125

Mazur P (2004) Principles of cryobiology. In: Fuller BJ, Lane N, Benson EE (eds) Life in the frozen state. CRC Press, Boca Raton, FL, USA, pp 3-65

Mazur P, Seki S, Pinn IL, Kleinhans FW, Edashige K (2005) Extraand intracellular ice formation in mouse oocytes. Cryobiology 51:29-53. https://doi.org/10.1016/j.cryobiol.2005.04.008

Meryman HT (1966) The interpretation of freezing rates in biological materials. Cryobiology 2:165-170. https://doi.org/10.1016/ S0011-2240(66)80163-3

Meryman HT, Williams RJ (1985) Basic principles of freezing injury to plant cells: natural tolerance and approaches to cryopreservation. In: Kartha KK (ed) Cryopreservation of plant cells and organs. CRC Press Inc., Boca Raton, pp 13-47

Nath J, Anderson JO (1975) Effect of freezing and freeze-drying on the viability and storage of Lilium longiflorum L. and Zea mays L. pollen. Cryobiology 12:81-88. https://doi.org/10.1016/ 0011-2240(75)90042-5

Nebot A, Philpott VJ, Pajdo A, Ballesteros D (2021) Cryopreservation of fern spores and pollen. In: Wolkers WF, Oldenhof $\mathrm{H}$ (eds) Cryopreservation and freeze-drying protocols. Springer, New York, pp 623-637

Normah MN, Makeen AM (2008) Cryopreservation of excised embryos and embryonic axes. In: Reed BM (ed) Plant cryopreservation: a practical guide. Springer, New York, pp 211-240
Oliver MJ, Farrant JM, Hilhorst HWM, Mundree S, Williams B, Bewley JD (2020) Desiccation tolerance: avoiding cellular damage during drying and rehydration. Annu Rev Plant Biol 71:435-460. https://doi.org/10.1146/annurev-arpla nt-071219-105542

Pacini E, Franchi GG (2020) Pollen biodiversity - why are pollen grains different despite having the same function? A review. Bot J Linn Soc 193:141-164. https://doi.org/10.1093/botli nnean/boaa014

Pammenter NW, Berjak P (1999) A review of recalcitrant seed physiology in relation to desiccation-tolerance mechanisms. Seed Sci Res 9:13-37. https://doi.org/10.1017/S0960258599000033

Pammenter NW, Berjak P (2000) Aspects of recalcitrant seed physiology. VII Brazilian Plant Physiology Congress. Sociedade Brasileira de Fisiologia Vegetal, Lavras, Brazil, pp 56-69

Pammenter NW, Berjak P (2014) Physiology of desiccation-sensitive (recalcitrant) seeds and the implications for cryopreservation. Int J Plant Sci 175:21-28. https://doi.org/10.1086/673302

Pammenter NW, Vertucci CW, Berjak P (1991) Homeohydrous (recalcitrant) seeds: dehydration, the state of water and viability characteristics in Landolphia kirkii. Plant Physiol 96:1093-1098. https:// doi.org/10.1104/pp.96.4.1093

Pammenter NW, Greggains V, Kioko JI, Wesley-Smith J, Berjak P, Finch-Savage WE (1998) Effects of differential drying rates on viability retention of recalcitrant seeds of Ekebergia capensis. Seed Sci Res 8:463-471. https://doi.org/10.1017/S096025850 0004438

Pammenter NW, Berjak P, Wesley-Smith J, Vander Willigen C (2002) Experimental aspects of drying and recovery. In: Black M, Pritchard HW (eds) Desiccation and survival in plants: drying without dying. CABI Publishing, London, pp 93-110

Pammenter NW, Naidoo S, Berjak P (2003) Desiccation rate, desiccation response and damage accumulation: Can desiccation sensitivity be quantified. In: Nicolás G, Bradford KJ, Côme D, Pritchard HW (eds) The biology of seeds: recent research advances. CABI Publishing, Wallingford, pp 319-325

Pegg DE (2007) Principles of cryopreservation. In: Day JG, Stacey GN (eds) Cryopreservation and freeze-drying protocols. Humana Press, Totowa, NJ, pp 39-57

Pritchard HW, Manger KR (1998) Calorimetric perspective on desiccation stress during preservation procedures with recalcitrant seeds of Quercus robur L. CryoLetters 19:23-30

Rajasekharan PE, Ravish BS, Kumar TV, Ganeshan S (2013) Pollen cryobanking for tropical plant species. In: Normah MN, Chin HF, Reed BM (eds) Conservation of tropical plant species. Springer, New York, pp 65-75

Sacks EJ, Clair DAS (1996) Cryogenic storage of tomato pollen: effect on fecundity. HortScience 31:447-448. https://doi.org/10.21273/ hortsci.31.3.447

Scheiwe MW, Korber C (1984) Thermally defined cryomicroscopy and thermodynamic analysis in lymphocyte freezing. Cryobiology 21:93-105. https://doi.org/10.1016/0011-2240(84)90026-9

Smirnoff N (1993) The role of active oxygen in the response of plants to water deficit and desiccation. New Phytol 125:27-58. https:// doi.org/10.1111/j.1469-8137.1993.tb03863.x

Smith AU (1961) Biological effects of freezing and supercooling. Edward Arnold, London

Smith AU, Smiles J (1953) Microscopic studies of mammalian tissues during cooling and rewarming from $-79^{\circ} \mathrm{C}$. J R Microscop Soc 73:134-139. https://doi.org/10.1111/j.1365-2818.1953.tb01980.x

Souza FVD, de Souza EH, da Silva RL (2018) Cryopreservation of pollen grains of pineapple and other bromeliads. In: Loyola-Vargas V, Ochoa-Alejo N (eds) Plant cell culture protocols methods in molecular biology. Humana Press, New York, NY, pp 279-288

Steponkus PL, Dowgert MF (1981) Gas bubble formation during intracellular ice formation. CryoLetters 2:42-47 
Stott SL, Karlsson JOM (2009) Visualization of intracellular ice formation using high-speed video cryomicroscopy. Cryobiology 58:84-95. https://doi.org/10.1016/j.cryobiol.2008.11.003

Sun WQ (2000) Dielectric relaxation of water and water-plasticized biomolecules in relation to cellular water organization, cytoplasmic viscosity, and desiccation tolerance in recalcitrant seed tissues. Plant Physiol 124:1203-1216. https://doi.org/10.1104/pp. 124.3.1203

Sun WQ (2021) DSC analysis of thermophysical properties for biomaterials and formulations. In: Wolkers WF, Oldenhof $\mathrm{H}$ (eds) Cryopreservation and freeze-drying protocols. Springer, New York, pp 285-302

van der Walt ID, Littlejohn GM (1996) Storage and viability testing of protea pollen. J Am Soc Hortic Sci 121:804. https://doi.org/10. 21273/jashs.121.5.804

Vertucci CW, Farrant JM (1995) Acquisition and loss of desiccation tolerance. In: Kigel J, Galili G (eds) Seed development and germination. Marcel Dekker Inc., New York, pp 237-272

Walters CT, Pammenter NW, Berjak P, Crane J (2001) Desiccation damage, accelerated ageing and respiration in desiccation tolerant and sensitive seeds. Seed Sci Res 11:135-148

Wesley-Smith J, Pammenter NW, Berjak P, Walters C (2001a) The effects of two drying rates on the desiccation tolerance of embryonic axes of recalcitrant jackfruit (Artocarpus heterophyllus
Lamk.) seeds. Ann Bot-Lond 88:653-664. https://doi.org/10. 1006/anbo.2001.1519

Wesley-Smith J, Walters CT, Pammenter NW, Berjak P (2001b) Interactions among water content, rapid (nonequilibrium) cooling to -196 degrees C, and survival of embryonic axes of Aesculus hippocastanum L. seeds. Cryobiology 42:196-206. https://doi.org/ 10.1006/cryo.2001.2323

Wolkers WF, Oldenhof H (2021) Principles underlying cryopreservation and freeze-drying of cells and tissues. In: Wolkers WF, Oldenhof $\mathrm{H}$ (eds) Cryopreservation and freeze-drying protocols. Springer, New York, pp 3-25

Xu J, Li B, Liu Q, Shi Y, Peng J, Jia M, Liu Y (2014) Wide-scale pollen banking of ornamental plants through cryopreservation. CryoLetters 35:312-319

Zhang J-M, Lu X-X, Xin X, Yin G-K, He J-J, Huang B, Jiang D, Chen X-L (2017) Cryopreservation of citrus anthers in the national crop genebank of China. In Vitro Cell Dev -P1 53:318-327. https://doi. org/10.1007/s11627-017-9848-Z

Publisher's Note Springer Nature remains neutral with regard to jurisdictional claims in published maps and institutional affiliations. 